\title{
"I SHALL TAKE THE LEAP TO THE GREAT BEYOND...": JOHANNES FAGAN'S STUDIES AND SUICIDE IN LONDON (1916-1920)
}

\author{
Heinrich van der Mescht \\ Department of Music, University of Pretoria, Pretoria, 0002
}

\begin{abstract}
"I shall take the leap to the great beyond...": Johannes Fagan se studie en selfmoord in Londen (1916-1920)
\end{abstract}

Dié artikel poog om die omstandighede van die studie en selfmoord van die Suid-Afrikaanse komponis Johannes Fagan (1898-1920) te rekonstrueer. Ten tyde van sy dood was hy 'n student aan die Royal College of Music (RCM) in Londen waar hy in September 1916, tydens die Eerste Wêreldoorlog, begin studeer het. Fagan sou in daardie tyd baie berigte oor die oorlog en die dood van RCM-studente moes aanhoor. In The R.C.M. Magazine sou hy Gurney se melankoliese gedigte, aangestuur van die front af, kon lees. Hy sou elke termyn se hoogs inspirerende openingstoespraak van die direkteur van die RCM, Hubert Parry, kon hoor. Na twee RCM-termyne het Fagan weens swak gesondheid vir twee jaar na Suid-Afrika teruggekeer. Tydens sy tweede studietydperk was hy 'n komposisiestudent van Vaughan Williams. Fagan is baie swaar getref deur die skielike dood van sy Engelse verloofde aan griep. Sy doodsertifikaat meld dat hy dood in sy bed aangetref is en dat hy sianied gedrink het. 'n Kort artikel hieroor het in The Kensington Express, Notting Hill and West London Examiner van Vrydag 23 Julie 1920 verskyn. Afgesien van sy inskrywingsvorm by die RCM, is die doodsberig wat in The R.C.M. Magazine verskyn het, die enigste plek waar Fagan se naam in die dokumente en publikasies van die RCM aangetref kan word.

Sleutelterme: Gideon Fagan, Johannes Fagan, Hubert Parry, Royal College of Music, SuidAfrikaanse komponiste, selfmoord

The article aims to reconstruct the circumstances surrounding the studies and suicide of the South African composer Johannes Fagan (1898-1920) while he was a student at the Royal College of Music (RCM) in London. Fagan started studying in September 1916 during World War I. He would have been confronted by many reports about the war and the death of RCM students. In The R.C.M. Magazine he would have read melancholy poems by Gurney, sent from the front. He would have attended the very inspiring opening addresses of the Director, Hubert Parry. After two terms of study, Fagan returned to South Africa for two years, owing to ill-health. In his second period of study he was a composition student of Vaughan Williams. 
Fagan was severely affected by the sudden death through influenza of his English fiancée. His death certificate states that he was "Found dead in his bed", and that he "Swallowed Cyanide solution poison". A short article about his death appeared in The Kensington Express, Notting Hill and West London Examiner of Friday 23 July 1920. Apart from his enrolment form, the fine obituary in The R.C.M. Magazine is the only place where Fagan's name can be found in the documents and publications of the RCM in London.

Key words: Gideon Fagan, Johannes Fagan, Hubert Parry, Royal College of Music, South African composers, suicide

\section{Introduction}

Thomas Chatterton, the precociously talented poet, was born in Bristol in 1752. In 1770 he decided to go to London where he wrote political satires, narratives and songs for many of the leading journals of the day. On 24 August 1770, the 17-year-old Chatterton was found dead in his attic room in Holborn, London. Chatterton became a Romantic hero, inspiring one of Coleridge's first poems, Monody on the death of Chatterton (1791-1794). Wordsworth wrote about "Chatterton, the marvellous boy / the sleepless soul that perished in his pride", and Keats dedicated his Endymion to Chatterton's memory in 1818.

In the Tate Britain art gallery in London there is a magnificent painting of Chatterton by Henry Wallis (1830-1916) [Figure 1]. Executed in 1855-1856, the painting shows the idealised young man lying on his bed in front of his attic window. ${ }^{1}$ His head, to the left, has a halo of bright orange-red hair encircling his greyish face. His left hand rests on his naked chest, and partly on his white shirt. He wears a bright blue knee length pair of trousers and white stockings. On his left foot he has a black shoe, the shoe of his right foot having fallen off. His right arm is suspended from the bed, his hand touching the floor. And near the hand on the plank floor there is a small glass vessel from which Chatterton took the arsenic. Behind the unhappy artist is a window where dawn is breaking over the roofs of London, with the silhouette of St. Paul's Cathedral in the distance. One of the panes is open, as though the poet's spirit has just departed to the great beyond. On the window sill: a red rose. And to the right of the bed, on a table: a spent candle, lit for or during the night, its faint last strain of smoke still hovering in the air; and a sheet of paper on which the author has perhaps left his last message.

In 1899, this painting was bequeathed to the Tate Gallery which was opened at Millbank in $1897 .{ }^{2}$ It is quite possible that a young music student studying in London would visit the Tate Gallery and see the painting.

\footnotetext{
A. Sturgis (et al.), Rebels and martyrs: The image of the artist in the Nineteenth Century (London, 2006), p. 84 .

A. Sturgis (et al.), Rebels and martyrs: The image of the artist in the Nineteenth Century, p. 84; Tate Gallery, in H. Osborne (ed), The Oxford Companion to Art (Oxford, 1984), p. 1122.
} 


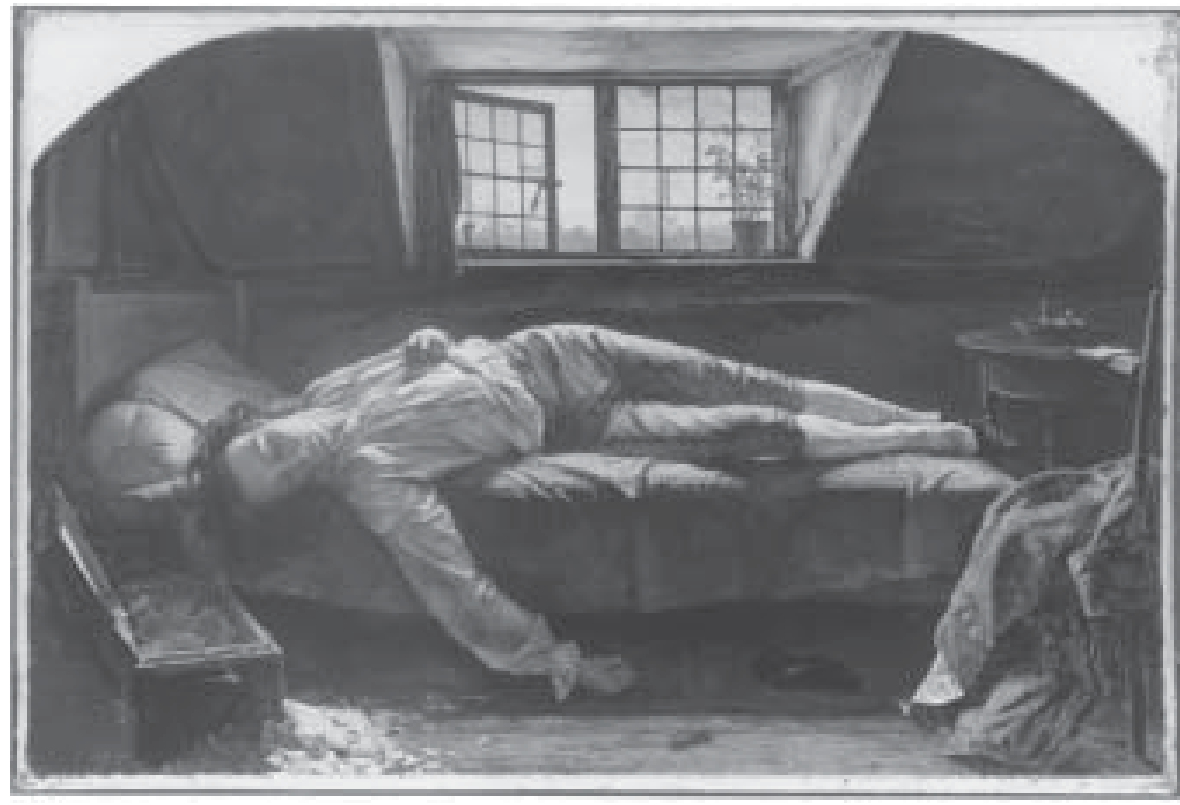

Figure 1: Henry Wallis: "Chatterton" (By kind permission of the Tate Gallery, London; Tate, (C) London, 2007.)

Johannes Fagan (1898-1920) [Figure 2] was a very promising 18-year-old South African musician who in 1916, in the middle of World War I, embarked from Cape Town on a long sea journey to the Royal College of Music (RCM) in London. Fagan's brother, Gideon Fagan, wrote the entry on him in the South African Music Encyclopedia. ${ }^{3}$ It provides a short biography and a list of his works. It is mentioned that Johannes Fagan committed suicide in 1920 at the age of 22 while a student at the Royal College of Music. But is there more information to clarify his death, and what were the circumstances of his suicide? How did the RCM and the daily papers respond to this terrible event? It is the aim of the present article to elucidate the context of these happenings which have hitherto apparently never been discussed in academic work. 


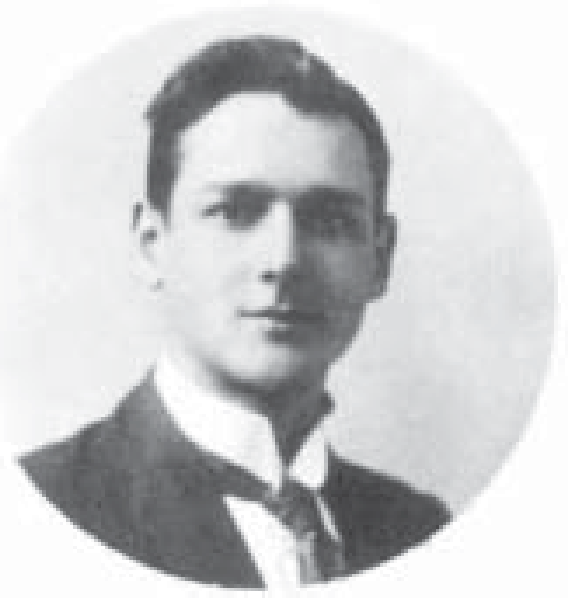

Figure 2: Johannes Fagan (Q. Fagan, Henry Allan Fagan 1889-1963, privaat uitgegee, Kaapstad, 1975, by kind permission of Gawie and Hannes Fagan).

\section{Investigation of available documentary sources}

There are four main sources in the archive and library of the RCM in London. ${ }^{4}$ The Students' registers provide information about each student's enrolment. Using a huge separate page for each student, it contains hand-written personal particulars, for example the date of enrolment, the date of leaving the RCM, the home address and the address where the student lived in London. Even the father's profession is filled in.

The RCM published an annual report of the previous year's activities. So, for example, the report for the academic year 1916/1917, Fagan's first year at the RCM, was published in 1918 with the title Report of the Council, Statements of Account, etc. for the year ending 31st August, 1917, and the proceedings at the Thirty-fourth Annual General Meeting of the Corporation, 21st March, 1918.

The R.C.M. Magazine, which appeared three times per year, is a very valuable source offering more general articles of a "student" type. It might include literary contributions by students, and would contain the beginning of term address to the students by the Director of the College.

I would like to acknowledge the help afforded to me by Mr Chris Bornet and Dr Peter Horton of the library and archive of the Royal College of Music in London. This article is based upon work supported by the National Research Foundation. Any opinions, findings and conclusions or recommendations expressed in this article are those of the author and therefore the NRF does not accept any liability in regard to these matters. 
The Minutes of the Executive and Finance Committees are also available. These meetings were held every few months. The minutes contain material about a variety of letters received, a report by the Director, information about scholarships awarded, details of finances, appointment of committees, decisions, particulars about students, etc.

There are no Fagan music manuscripts in the archive of the RCM in London, nor any letters from or to him. Fagan's death certificate can be found in the Family Records Centre at 1 Myddelton Street, London. Bouws's chapter on "Johannes en Gideon Fagan” does not provide information about Johannes Fagan's death, but Henning mentions the way in which Fagan committed suicide. ${ }^{5}$

\section{Johannes Fagan: a short biography}

Johannes Fagan came from an extremely talented family. His father was Henry Allan Fagan (1865-1931) and his mother Catherina Susanna Smith (1864-1937), a sister of the extraordinarily versatile Afrikaans philologist and lexicographer Prof J.J. Smith (1883-1949), who, amongst other things, earned a BA Hons from the University of London. ${ }^{6}$ Fagan's elder brother, also Henry Allan Fagan (1889-1963), was an Afrikaans poet and playwright who became the Chief Justice of South Africa. A poem by brother H.A. Fagan was used by Johannes Fagan for the song Soos die windjie wat suis. A younger brother, Gideon Fagan (1904-1980), followed in his late brother Johannes's footsteps and studied at the RCM. ${ }^{7}$

Johannes Jacobus Fagan, born in Tulbagh on 22 February 1898, was 16 years old when he enrolled in 1914 at the South African College of Music in Cape Town. The College was founded in 1910. Here Fagan had the privilege of studying with William Henry Bell (18731946) who came to South Africa in 1912 as Head of the College of Music. From 1909 to 1912 Bell had been a professor of harmony at the Royal Academy of Music in London. ${ }^{8}$ He later became the composition teacher of some of South Africa's leading composers, for example Hubert du Plessis, Stefans Grové and John Joubert. In 1916 Fagan won a three year scholarship to the RCM, ${ }^{9}$ but as he had been suffering from ill-health, had to return to South Africa. According to his enrolment form "Mr Fagan returned to Africa at the beginning of Easter Term

\footnotetext{
5 J. Bouws, Suid-Afrikaanse komponiste van vandag en gister (Kaapstad, 1957), pp. 49-51; C.G. Henning, Fagan, Johannes Jacobus, in C.J. Beyers (Editor-in-chief), Dictionary of South African Biography 4 (Durban, 1981), p. 152.

$6 \quad$ W.J. de Kock and D.W. Krüger, Smith, Johannes Jacobus, in W.J. de Kock and D.W. Krüger (eds), Dictionary of South African Biography 2 (Cape Town, 1972), pp. 677-679.

C.G. Henning, Fagan, Johannes Jacobus, in C.J. Beyers (Editor-in-chief), Dictionary of South African Biography 4, p. 152.

$8 \quad$ R. Barnett, Bell, W(illiam) H(enry), in S. Sadie (ed), The New Grove Dictionary of Music and Musicians 3 (2nd edition), (London, 2001), p. 183.

G. Fagan, Fagan, Johannes Jacobus, in J.P. Malan (ed), South African Music Encyclopedia 2 (Cape Town, 1982), p. 51.
} 
1917 on account of ill-health." Fagan was in London for about six months only. He resumed his studies with Bell in Cape Town and in 1919 his Prelude for Orchestra was premièred by the Cape Town Municipal Orchestra in the City Hall of Cape Town, conducted by Theo Wendt (1874-1951). This orchestra was founded in 1914, and was therefore only five years old. It was a great achievement for a young composer to have his work performed by an orchestra. In Q. Fagan's book Henry Allan Fagan 1889-1963 it is even maintained that it was the first performance of a South African's composition by a symphony orchestra. ${ }^{10}$

Having recuperated, Fagan returned to London shortly after this performance. His enrolment form at the RCM states that he "Reentered Midsummer Term 1919" and that his fees were paid on 28 April 1919. He had therefore been in South Africa for more than two years. "Both in Cape Town and London high hopes were held for Fagan's future". ${ }^{11}$ On 13 July 1920 he committed suicide, leaving some finished and some unfinished manuscripts. ${ }^{12}$

\section{The Royal College of Music in 1916}

From 1895, the RCM had been under the directorship of Sir Hubert Parry (1848-1918) who had succeeded the first Director, Sir George Grove. ${ }^{13}$ By 1916, more than 20 years later, Parry was 68 years old and had gathered wide experience of running a prosperous institution and of the characteristics of the successful student musician.

In his "Director's Address" of 1 May 1916, printed in The R.C.M. Magazine and probably read by Fagan, ${ }^{14}$ Parry started with the following paragraph: ${ }^{15}$

$10 \quad$ Privaat uitgegee, Kaapstad, 1957, p. 54.

11 G. Fagan, Fagan, Johannes Jacobus, in J.P. Malan (ed), South African Music Encyclopedia 2, p. 51.

12 Apart from the Prelude for orchestra, Gideon Fagan mentions the following completed works: Love-sick am $I$ (Robert Herrick) and Kyrie eleison for mixed chorus or vocal quartet; the songs for voice and piano Soos die windjie wat suis (H.A. Fagan), Die soekende moeder (Jan F.E. Celliers), I saw a cherry weep (Robert Herrick), and The vision to Elektra (Robert Herrick); a Piano Sonata in C sharp Minor, Intermezzo in D flat major, Etude in A flat major, and Notturno for piano solo; and a cadenza to Mozart's Piano Concerto in B flat major K. 450. Of these only the two Afrikaans songs were published. See G. Fagan, Fagan, Johannes Jacobus, in J.P. Malan (ed), South African Music Encyclopedia 2, p. 51.

13 J. Dibble, Parry, Sir (Charles) Hubert (Hastings), in S. Sadie (ed), The New Grove Dictionary of Music and Musicians 19 (2nd edition), (London, 2001), p. 153.

14 Fagan came from a family of avid readers. As a preparation for his studies he could have found this copy in Cape Town where there was a number of former RCM students.

15 C.H.H. Parry, Director's Address: May 1, 1916, The R.C.M. Magazine 12(3), 1916, p. 71. The magazine was first published for the Christmas term of 1904. In Volume 4(1) (pp. 4-5) there appears, for the first time, Notes of the Director's Address: Christmas Term, 1907, and in Volume 4(2) (pp. 37-38) follows Notes in brief from the Director's Address: Easter Term, 1908. But in the next issue (Volume 4(3), pp. 65-70), The Director's Opening Address: Midsummer term, 1908 is apparently printed in its complete form for the first time. The Director's Address was included in every R.C.M. Magazine thereafter. These addresses were delivered to the students at the beginning of every term. Parry's addresses were later edited by H.C. Colles and published in 1920 by Macmillan. 
It is very useful to have to adapt ourselves to changed conditions. Everything that has life in it is always changing, and if people cannot adapt themselves they get left behind and cease to take part in the general progress of the world.

Parry goes on to philosophise about changes in general life and particularly at the College. These were difficult times for the institution, with some students already killed in the war. ${ }^{16}$ Certain activities of the College had to be curtailed. So, for example, the wind ensemble class had to be cancelled as "there was only one wind instrument player left to assemble with, the rest having been drawn off into various branches of the fighting services." ${ }^{17}$ Also the annual opera had to be forfeited.

The year 1916 was an interesting one for the RCM. It was "the longest year the College has ever lived through," Parry said in his address of 25 September $1916 .{ }^{18}$ The College had decided to extend the academic year 1915/1916 to the end of the Summer term. From then on the year would go from September to August instead of from May to April. ${ }^{19}$ This meant that the previous academic year was sixteen months long. On this occasion, Parry specially mentioned some exceptional students, one of whom was Kathleen Long (1896-1968), two years older than Fagan. ${ }^{20}$ Parry declared:

Miss Long has been a very frequent source of delight to us. In her case, too, the natural musical outfit is of the rarest quality. We are thankful that she is not an illustration of mere artificially-developed virtuosity. The virtuosity has come on the top of a genuinely musical nature, full of insight and feeling. She delights us equally in the most fantastic flights of modern French composers, and in the deeper and more fervent inspirations of the great masters of the past. I think she has won almost every available prize for pianists at the College, and she has also won what is even better - the good will and esteem of everyone who is any judge of character. Her admirable gifts are well matched by her qualities of disposition, and, if ability and character are of any avail in our world of art, Miss Long should be destined to a distinguished career. ${ }^{21}$

16 The R.C.M. Magazine 12(3), pp. 89-92 provides a list: "The following Pupils, past and present, have joined the Army since the outbreak of the war." In his Director's Address of 25 September 1916 Parry mentions the singer Eric Roper, the composer George Butterworth and the horn player Adolph Goossens as some of those who had fallen. See C.H.H. Parry, Director's Address: September 25, 1916, The R.C.M. Magazine 13(1), 1916, pp. 7-8. It was stated, "[S]ome of our most gifted and valued pupils have laid down their lives". See $R C M$ Report 1917 (London, 1918), p. 13.

17 C.H.H. Parry, Director's Address: May 1, 1916, The R.C.M. Magazine 12(3), 1916, p. 72.

18 C.H.H. Parry, Director's Address: September 25, 1916, The R.C.M. Magazine 13(1), 1916, p. 4.

19 RCM Report 1917 (London, 1918), p. 11.

20 She later taught the piano at the RCM between 1920 and 1964. See C. Timbrell, Long, Kathleen, in S. Sadie (ed), The New Grove Dictionary of Music and Musicians 15 (2nd edition), (London, 2001), p. 167.

21 C.H.H. Parry, Director's Address: September 25, 1916, The R.C.M. Magazine 13(1), 1916, p. 6. 


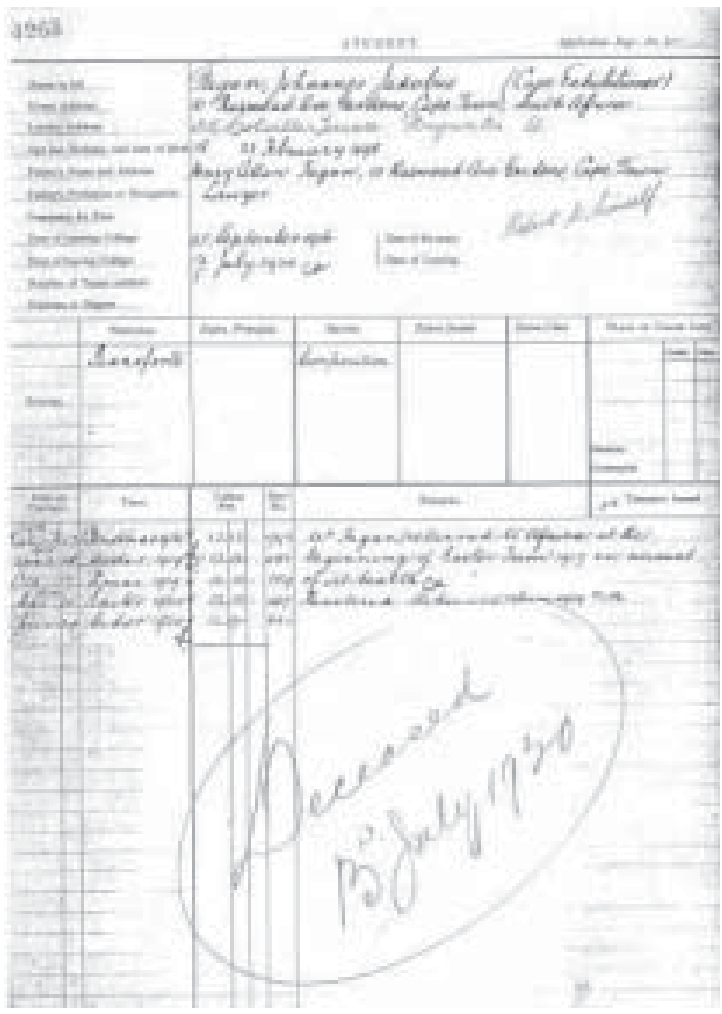

Figure 3: Fagan's enrolment form at the RCM (by kind permission of the Royal College of Music, London)

One of the new students who might have heard this eulogy was Johannes Fagan who enrolled at the RCM on 25 September 1916, the same day as Parry's speech [Figure 3]. The example of Kathleen Long would certainly have set a standard for the 18-year-old. Parry's addresses often contain inspiring sections for the benefit of his students, explicating his views on music and the musician. An example is the following: ${ }^{22}$

We know from happy experience how music can take possession of us. It insinuates itself into our very being and displaces all else for the time that we are filled with it. When music is noble and elevated it communicates its nobility to us. And also, 
unfortunately, when it is paltry and trivial it communicates to us its paltriness and triviality. The music that can worthily minister to souls that are torn by the loss of those we love best and need most, has to be of deeper quality.

On the topic of the musician, he continued:

It seems to be part of the common misconception that people who pursue art ought to have unlimited leisure and be shielded from annoyances and interruptions. It seems likely that new experiences will offer us new and saner views. [...] But those who survive [the war] will bring home to us rather forcibly the fact that for the artistic nature, as well, indeed, as for most other kinds of spiritual activity, the realities of active life are the finest of nurture. The shielded type of human being never achieves anything of the finest quality. He merely relapses by degrees into self-indulgence and self-worship, and possibly into the pursuit of that pernicious will-o'-the-wisp called pleasure. ${ }^{23}$

It is into this atmosphere of disciplined, idealistic education and the all-pervasive presence of war that Johannes Fagan was transplanted from Cape Town. Whereas there were 336 pupils in May 1915, there were 246 at the end of the Summer Term of $1916 .{ }^{24}$ For the academic year ending 31 August 1917 in which Fagan enrolled there was a total of only $227 .{ }^{25}$ At the beginning of the 1918/1919 year (in September 1918) the number was 231, but at the end of that academic year (August 1919, after the war had ended) it was 332. Numbers had reached "well over 500" by May 1920. ${ }^{26}$ The RCM had survived the turmoil of war: From 227 students at the time of Fagan's enrolment, the numbers had increased to more than 500 at the time of his death.

\section{Fagan's study periods at the RCM (1916-1917, 1919-1920)}

The enrolment form of student number 4265, Johannes Jakobus (sic) Fagan, discloses that his father was Henry Allan Fagan, a lawyer from 10 Rosmead Avenue, Gardens, Cape Town.

There is only one London address on the enrolment form: " 35 Colville Terrace, Bayswater W.", filled in later than the rest of the information. It could be that Fagan arrived without permanent accommodation and only found it once he was in London. His address was in a suburb of London called Notting Hill and relatively close to the underground station Notting Hill Gate. Today this address is a terraced house with a basement apartment and four storeys

23 C.H.H. Parry, Director's Address: September 25, 1916, The R.C.M. Magazine 13(1), 1916, p. 10. Parry gave his last Director's Address on 29 April 1918 and died on 7 October of that year. See C.H.H. Parry, Director's Address: April 29th, 1918, The R.C.M. Magazine 14(3), 1918, pp. 68-74. 


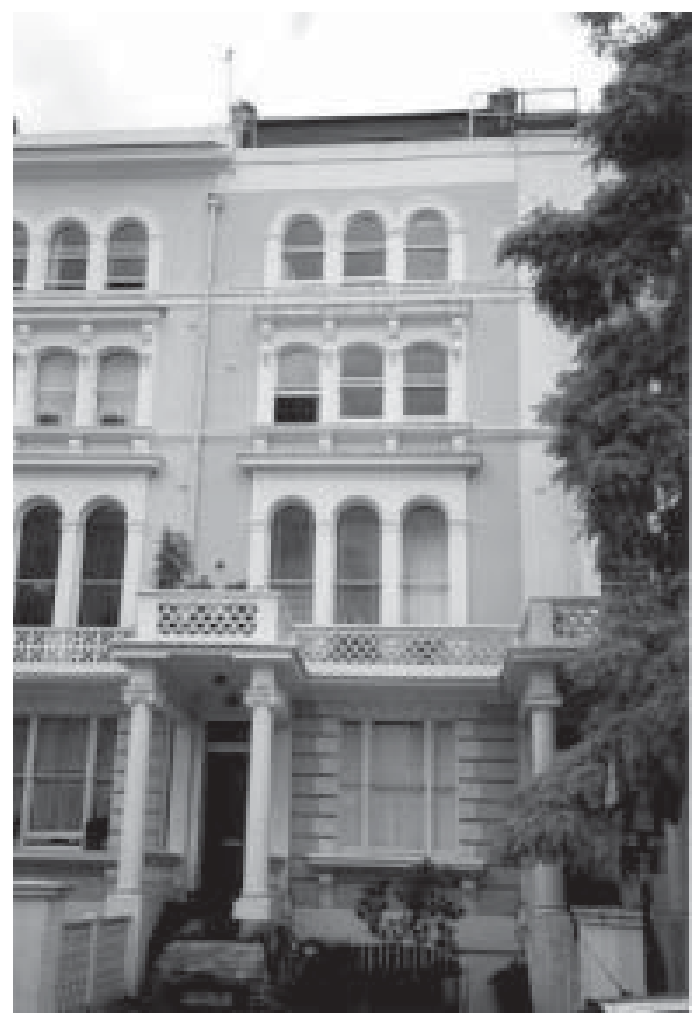

Figure 4: The first building in which Fagan stayed in London: 35 Colville Terrace, Bayswater (Photograph: Heinrich van der Mescht)

[Figure 4]. As can be seen at some of the houses on that side of the street, the building would in Fagan's time have had a small garden in front, now replaced with pavement providing space for two cars and six rubbish bins. There are at least five flats in the building. Fagan could have used the underground from Notting Hill Gate or the bus to get to the RCM, or he might have walked from his lodgings which would have taken him about 30 minutes. His way would have led him through the lovely Kensington Gardens with its very old trees and pathways. He would have passed the gloriously ornamented Albert Memorial, crossed Kensington Road, walked round the Royal Albert Hall (with the former home of the RCM on his right, later used by the Royal College of Organists) and then seen the impressive edifice of the Royal College of Music in front of him.

During the academic year in which Fagan enrolled (1916/1917), the complete list of students shows that there were eight South Africans at the time. ${ }^{27}$ Among these students were 
some who became foremost students at the RCM. The list gives the "Name", "Residence" (town and/or country) and "Principal Study":

$\begin{array}{llll}\text { Gladys E. Bell } & \text { Durban } & \text { Singing } & \text { [Jan. 1916 - March 1918] } \\ \text { Harry Cantor } & \text { Yeoville } & \text { Violin } & \text { [Oct. 1914 - July 1917] } \\ \text { Julia Carmel } & \text { Cape Town } & \text { Violin } & \text { [Sept. 1915 - July 1917] } \\ \text { Johannes J. Fagan } & \text { South Africa } & \text { Pianoforte } & \text { [Sept. 1916 - July 1920] } \\ \text { Thelma B. Halse } & \text { Cape Province } & \text { Singing } & \text { [June 1916 - Feb. 1918] } \\ \text { Alice M. Mattingley } & \text { Port Elizabeth } & \text { Singing } & \text { [Sept. 1915 - July 1917] } \\ \text { Nancy F. Phillips } & \text { Cape Province } & \text { Violin } & \text { [Sept. 1912 - Dec. 1917] } \\ \text { Moira B.B. Slater } & \text { Johannesburg } & \text { Violin } & \text { [May 1915 - March 1918] }\end{array}$

To this list must be added those pupils who for some reason were classified under another place of residence (for example: they were not born in South Africa, but grew up there). Their names can, however, not be deduced from the list provided.

Three of the South African students had arrived with a prestigious scholarship from the University of the Cape of Good Hope: Nancy Phillips won it for September 1912 to July 1915, Harry Cantor for September 1914 to July 1917, and Julia Carmel for September 1915 to July $1917 .{ }^{29}$ All were violinists.

Fagan's name could not be found in the many lists of students who obtained scholarships and prizes of different sorts at the RCM. It has to be deduced that he was not one of the very best of the students. But the singer Miss A. May Mattingley from Port Elizabeth was one of only 12 candidates who received an "Open Scholarship" after the competition in June 1917. ${ }^{30}$ She later relinquished it and thus received the title "Honorary Scholar." ${ }^{31}$ (Eight other students had their scholarships renewed.) The violinist Nancy Phillips, who was a "Charlotte Holmes Exhibitioner" worth $£ 15,{ }^{32}$ and had gained the diploma of Associate of the Royal College of Music (ARCM), won the Manns Memorial Prize of $£ 410$ s as well as the Gowland Harrison Exhibitioner of $£ 40$ for May 1917 to March $1918,{ }^{33}$ a considerable amount. (She apparently left the RCM before the end of this period.) She was also the recipient of a prize of a violin bow and case from W.E. Hill and

\footnotetext{
27 RCM Report 1917, pp. 65-68. This report is of great value as it supplies a complete list of the students enrolled during the year, which the next reports do not include.

28 The list of dates is provided to aid researchers who might be interested in these persons.

29 RCM Report 1917, p. 37. Fagan's name does not appear in the RCM's lists of scholarship holders. It could not be determined what scholarship he had received.

RCM Report 1917, p. 13.

Archive of the RCM, London, RCM Minute Book 12, p. 96.

RCM Report 1917, p. 36

RCM Report 1917, pp. 16, 39.
} 
Sons and the Scholefield Prize of $£ 3$ for $1916 .{ }^{34}$ Moira Slater won one of the Council Exhibitions for the Midsummer Term of $1917 ;^{35}$ this was previously awarded to Nancy Phillips in the Midsummer Term of $1915 .{ }^{36}$ It is evident that the South African students could be regarded as of a high standard. It is perhaps because of ill-health that Johannes Fagan could not join the ranks of the successful South African students at the RCM.

There were six orchestral concerts and twelve chamber music concerts presented by the RCM during the academic year 1916/1917. ${ }^{37}$ According to his enrolment form Fagan initially only stayed for one term, as he returned home at the beginning of the Easter Term of 1917 because of his bad health. This would have been in about March of 1917. Until this date Fagan could have heard orchestral works by past and present pupils of the College being performed, among them Hamish MacCunn, Arthur Benjamin, Ernest Farrar and Ivor Gurney. The last three were on active service. Other composers represented were Boëllmann, Borodine, Dvoøák, Elgar, Franck, Grieg, Liszt, MacDowell, Moussorgsky, Ponchielli, Puccini, Purcell, Smetana, Tchaikovsky and Verdi. Fagan was also exposed to performances of chamber music by British composers like Bantock, Bridge, Ireland and Somervell.

The leading South Africans (but not Fagan) often performed at the RCM concerts. At the first concert listed for the academic year 1916/1917, on Thursday 19 October 1916, Fagan's countryman Harry Cantor was the first violinist in a performance of the String Quartet in G major op. 64 no. 4 by Haydn. May Mattingley sang the "Mad Bess" scene by Purcell, conducted by Sir Charles Villiers Stanford at the next concert on Friday 27 October 1916. ${ }^{38}$ And at the third concert, on Thursday November 1916, Nancy Phillips was the second violinist in a performance of Beethoven's String Quartet op. 95 and the violinist in the "Trio for Pianoforte and Strings" by her fellow student Stanley H. Wilson. ${ }^{39}$ On Thursday 7 December 1916 Miss Phillips played Bach's concerto for Violin in E major, accompanied by strings. She was on stage again on Thursday 1 February 1917 as the second violinist in Brahms's String Quartet in A minor op. 51 no. $2 .{ }^{40}$ On the same programme Franck's Piano Quintet was interpreted with Miss Phillips as first violinist joined by Harry Cantor as second violinist. This was followed on Thursday 8 March with the première of Stanley H. Wilson's String Quartet in A minor in which Phillips played the first violin part with Harry Cantor playing the second. The next week, on Thursday 15 March 1917, Miss Phillips performed the Sonata for Piano and Violin in A major op. 13 by Fauré with Kathleen Long. Parry wrote about it in his report to the Executive and Finance Committees: "A Quartet which had been

RCM Report 1917, pp. 43, 44.

RCM Report 1917, p. 17.

RCM Report 1916, p. 20.

RCM Report 1917, p. 9.

College Concerts, The R.C.M. Magazine 13(1), 1916, p. 26.

College Concerts, The R.C.M. Magazine 13(1), 1916, p. 27.

College Concerts, The R.C.M. Magazine 13(2), 1917, p. 55. 
prepared had to be given up at the last moment, and Miss Kathleen Long, ex-scholar, saved the situation by playing with Miss Nancy Phillips, at twenty-four hours' notice [...], with admirable effect." ${ }^{41}$ Nancy Phillips was clearly one of the leading students at the RCM. The high quality of the South African violinists' playing was again illustrated in the performances of Harry Cantor (first violin) and Nancy Phillips (second) in Beethoven's String Quartet in G major op. 18 no. 2 on Thursday 24 May 1917. This programme included Brahms's Piano Trio in $\mathrm{C}$ minor op. 101 in which Miss Phillips took the violin part. (The concert took place after Fagan had left the RCM to return to South Africa. $)^{42}$

If Fagan could have attended the concerts at the RCM, they would certainly have inspired him. At the students' concert on Monday 11 December 1916 he could have heard the first performance of the Dance-Scherzo for orchestra by Arthur Benjamin (1893-1960), "written in the trenches." The concert was conducted by Stanford. ${ }^{43}$

Fagan must have been reminded of the war on many occasions. The first R.C.M. Magazine of the 1916/1917 academic year (Volume 13 no. 1) contains literary contributions by past students from the front: an essay, "A Camp Concert in France", by Arthur Benjamin, and poems by Ivor Gurney, "The fire kindled" and "Strange service". Poems by Gurney were to appear in The R.C.M. Magazine regularly during the war years, most likely also read by Johannes Fagan in London and Cape Town where there were several ex-RCM students. A review by "M.M.S." (Marion Scott) of Gurney's volume of poetry Severn and Somme appeared in Volume 14 no. 1 of The R.C.M. Magazine. The magazine also published obituaries of those fallen in the war, and in his Director's Address of 24 September 1917 Parry spoke at length about the loss of RCM students, "dwelling on the memories of beloved ones whom we shall never see at the College any more", and calling Francis Purcell Warren one of "those most

$41 \quad$ Archive of the RCM, London, RCM Minute Book 12, p. 87.

$42 \quad$ College Concerts, The R.C.M. Magazine 13(3), 1917, p. 88. Harry Cantor had enrolled on 7 October 1914 when he was 17 years old. He was student number 4082. His father's address was "4 Muller Street, Yeoville, SAfrica". Born on 3 September 1897, he was about six months older than Fagan. It is evident from the many times Cantor appeared at the official chamber music concerts that he was one of the leading violinists at the RCM. Cantor was the star of the concert of Thursday 5 July 1917: he played two solos (Romance by Mandl and Scherzando by Marsick) and was the second violinist in a performance of the String Quartet in G major op. 106 by Dvoøák. See College Concerts, The R.C.M. Magazine 13(3), 1917, p. 88. Cantor is not included in any of the concerts of the Christmas Term of 1917. See College Concerts, The R.C.M. Magazine 14(1), 1917, pp. 20-21. Fagan did not see Cantor on his return in 1919: apparently Cantor died some time after his last concert of 5 July 1917. No "Date of leaving College" was noted on his enrolment form, and instead "Deceased" was written. In addition, opposite the entry for the Midsummer Term of 1917 (the last entry) for which payment was made on 7 June 1917 the word "Deceased" was written under "Remarks". This leads one to think that Cantor might have died during the term. Cantor's name is, however, not included in the Death Register of England and Wales which can be inspected at the Family Register Centre in London. It was clearly noted on his enrolment form that he studied only until the Summer Term of 1917. Cantor must have died in some other place and not in England. There is no entry on Cantor in the South African Music Encyclopedia. College Concerts, The R.C.M. Magazine 13(1), 1916, p. 27. 
lovable boys". ${ }^{44}$ About another student Parry wrote in his confidential report on the Midsummer Term of 1917 to the Executive and Finance Committees:

The strangest and most cruel of the tragedies seems to be the case of Douglas Fox, who was one of the finest Organists in this country, and also a very gifted Pianist, as he won the Challen Gold Medal for Pianoforte playing in 1912. He promised to become one of the foremost Musicians of his time. He was quite unfit for the barbarities of warfare, but faced them with noble spirit, and in the end the dreaded calamity fell upon him, as he was badly wounded in the right arm, and so to save his life it had to be amputated, and his opportunity of bringing honour to the country and the College is utterly destroyed. ${ }^{45}$

The RCM was reminded of the realities of the war when during an air raid on 1 October 1917 a "shrapnel shell-case penetrated the Concert Hall roof, causing damage to the ceiling and Orchestra platform." 46

According to the South African Music Encyclopedia, Johannes Fagan studied with Vaughan Williams, ${ }^{47}$ but the RCM Report 1917, covering Fagan's first period of study, shows that composition was taught by Stanford, Charles Wood and Walford Davies. ${ }^{48}$ Vaughan Williams is included in the "Teaching Staff" of 1918/1919 together with Holst, Stanford and Wood. ${ }^{49}$ So Fagan would have studied with Vaughan Williams during his second period at the RCM. He would most probably have made the acquaintance of Ivor Gurney (1890-1937) who, after initially having studied with Stanford, enlisted for the war. He survived, but had to spend time in army general and mental hospitals. In October 1918 he resumed his studies at the RCM, this time with Vaughan Williams. ${ }^{50} \mathrm{He}$ could have met Johannes Fagan at this time..$^{51}$

It is most likely that Fagan would have had the time shortly after arriving at the RCM in 1916 to read Ivor Gurney's poem "Firelight", written in France during the war, and published in The R.C.M. Magazine. ${ }^{52}$ The last stanza of the poem reads as follows:

\footnotetext{
44 C.H.H. Parry, Director's Address: September 24, 1917, The R.C.M. Magazine 14(1), 1917, pp. 6, 4.

45 Archive of the RCM, London, RCM Minute Book 12, p. 103.

$46 \quad$ Archive of the RCM, London, RCM Minute Book 12, p. 107.

47 G. Fagan, Fagan, Johannes Jacobus, in J.P. Malan (ed), South African Music Encyclopedia 2, p. 51.

$48 \quad$ RCM Report 1917 , p. 32.

$49 \quad$ RCM Report 1919, p. 38.

50 M. Hurd, Gurney, Ivor (Bertie), in S. Sadie (ed), The New Grove Dictionary of Music and Musicians 10 (2nd ed), (London, 2001), p. 595. Gurney won the Arthur Sullivan Prize for Composition in 1919. See RCM Report 1919, p. 40.

$51 \quad$ It is interesting to note that Gurney's song "Tears" was performed within his group of Five Elizabethan Songs at the student concert on Thursday 28 February 1918. See College Concerts, The R.C.M. Magazine 14(2), 1918, p. 58. It uses a poem by John Fletcher, starting with "Weep you no more, sad fountains". Fagan worked on "Tears" by Walt Whitman which he set for baritone and orchestra, but he did not finish the work. The material was used by his brother Gideon Fagan for a tone poem for solo voice, mixed choir and orchestra, using the same title. See G. Fagan, Fagan, Johannes Jacobus, in J.P. Malan (ed), South African Music Encyclopedia 2, p. 51. Perhaps the choice of poems with this title indicates the two composers' melancholy character. I. Gurney, Firelight, The R.C.M. Magazine 13(2), 1917, p. 62.
} 
And yet, they have no skill of words, whose eyes glow so deep,

They wait for night and silence and the strange power of Sleep,

To lift them and drift them like sea birds over the sea,

Where someday I shall walk again, and they walk with me.

The name of Johannes Fagan does not appear in the annual yearbooks as a performer or as a winner of a scholarship. Perhaps he was simply too ill to produce his best. The RCM was badly affected by the flu epidemic. In the Terminal Report on the Christmas Term of 1918 delivered on 30 January 1919 the following is written about the epidemic:

The difficulties of the College [after the retirement and death of Parry in October 1918] were afterwards increased by the prevalence of the epidemic of influenza and pneumonia, from which London suffered during the autumn and early winter, and from time to time members of both the teaching and administrative staffs, as well as many students, were kept away from work by illness. ${ }^{53}$

Parry did not live to experience the armistice, dying on 7 October 1918. On 8 November 1918 a memorial concert for Hubert Parry was given consisting of his own compositions. ${ }^{54}$ The conductors were Walter Parratt and Charles Stanford. A Memorial Service was held on 19 March 1919 in the Temple Church for pupils of the Royal Academy of Music and the RCM who had fallen in the war. ${ }^{55}$

In the minutes of the Executive and Financial Committees of 20 March 1919 it was mentioned that the cancellation of Ethel F. Visser's Student's Agreement was authorized. ${ }^{56}$ "(May have returned to South Africa)" was added. But the interruption of Fagan's studies and his return to South Africa are mentioned on his enrolment form only. According to this form, Fagan returned to the RCM in March 1919 after an absence of a little more than two years. Here he was to stay for four terms. Fagan would most probably have heard the new Director's Address of 28 April 1919, in which Hugh Allen (1869-1946), who succeeded Parry, said the following:

Will you let me say a few words as to what one means by a full musical life and how one can make the opportunities which this place affords administer to the needs of this life. [...] No amount of individual lessons is going completely to create the atmosphere necessary to the well-being of a thorough-going music student. ${ }^{57}$

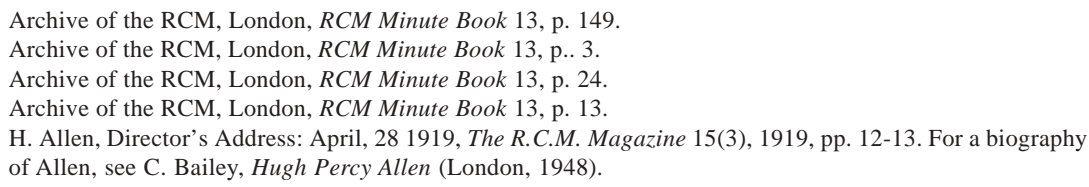


To commemorate the 25 years in the new (and present) building of the RCM, a series of three concerts was arranged for 1, 2 and 4 July 1919. ${ }^{58}$ These programmes consisted of works by composers connected with the RCM. Composers represented were Edgar Bainton, Bridge, Butterworth (killed in action), Coleridge-Taylor, Harald Darke, Walford Davies, Dunhill, Ernest Farrar (killed in action), Nicholas Gatty, Eugene Goossens, Gurney, Holst, Howells, Hurlstone, Ireland, Henry D. Ley, Parry, Cyril Rootham, Arthur Somervell, Stanford, Vaughan Williams, F. Purcell Warren (reported missing), Stanley Wilson and Charles Wood. The conductors were, amongst others, Allen (the director of the RCM), Boult, Bridge, Dunhill, Holst, Stanford and Wood. One wonders what impression this show of the importance of British composers would have made on an Afrikaner like Fagan (if he were there).

On 11 November 1919 (a year after the armistice) a short gathering was held in the Concert Hall of the RCM to commemorate those who had died during the war. The Director, Hugh Allen, read out the names of 36 College students. ${ }^{59}$ Then Parry's famous Jerusalem was sung.

\section{Fagan's suicide on Tuesday 13 July 1920}

According to Henning, Johannes Fagan was not without family in London: his two sisters were studying there at the time of his death. ${ }^{60}$

On Tuesday 13 July 1920 Johannes Fagan committed suicide at 13 Colville Road in Bayswater. On a recent visit to the street, this address could not be found. The numbers in the street start with number 19 . Where number 13 would have been, there is a five-storeyed block of flats called Portobello Court. Very close to this address and Fagan's first London address of 1916 there is All Saints Notting Hill, a Church of England. According to a plaque in the entrance hall to the church, the building was twice severely damaged during World War II, on 26 September 1940 and 19 June 1944. It is possible that 13 Colville Road suffered the same fate and that one can no longer stand at the door of the house where Fagan died.

The death certificate held in the Family Register Office in London discloses that Fagan was "Found dead in his bed," and that he "Swallowed Cyanide solution poison / Killed himself during a state of temporary insanity". The inquest was held on 16 July and the registration was done on 17 July in the district of Kensington North.

There were different daily and weekly papers which could comment on the events of the fatal day, but nothing about Fagan's death could be found in the weekly papers Paddington Mercury and West London Star of Friday 16, 23 and 30 July 1920, Paddington News of

Three Festival Concerts, The R.C.M. Magazine 15(3), 1919, pp. 8-10.

Editorial, The R.C.M. Magazine 16(1), 1919, p. 3.

C.G. Henning, Fagan, Johannes Jacobus, in C.J. Beyers (Editor-in-chief), Dictionary of South African Biography 4, p. 152. 
Friday 16, 23 and 30 July 1920, The Paddington Gazette and Weekly Register of Saturday 17, 24 and 31 July 1920, and The Paddington, Kensington and Bayswater Chronicle of Saturday 17, 24 and 31 July 1920.

But on 23 July 1920 an article appeared in The Kensington Express, Notting Hill and West London Examiner (a Friday paper) entitled A student's suicide: his letter to the coroner: ${ }^{61}$

An inquest was held at the Kensington Coroner's Court on Friday on the body of Johannes Jacobus Fagan, 22 years, a young South African composer and student of music, of 13, Colville Road, Bayswater, who was found by his laulady [sic] (Mrs. Stokes) dead in bed with a bottle of cyanide on a table and a letter addressed to the Coroner.

The note found in the room read "2.40 a.m. I am waiting the last four minutes for peace. At 2.45 I shall take the leap to the great beyond... A minute and a half and I must pour out the draught. Can it be that all this suffering is nearly over. Good-bye, good-bye, friends all."

Dr. Marks Golding, of Dawson Place, who was fetched, said death was due to poisoning by cyanide of potassium. Witness had attended the deceased for a year, and, in his opinion, he was insane and suicidal, especially since the death of the girl he was engaged to. ${ }^{62}$

Mr. Oswald said the young man was evidently contemplating the idea of his death with pleasure and recorded a verdict of "Suicide during temporary insanity". ${ }^{63}$

Johannes Fagan was not forgotten in The R.C.M. Magazine. The following anonymous obituary appeared soon after his death: ${ }^{64}$

\section{JOHANNES J. FAGAN}

We regret to record the death on July 13th of JOHANNES J. FAGAN. He was so modest himself, so retiring, and so little inclined to believe that he was held in high personal regard by others that it would probably surprise him greatly to learn with what genuine sorrow his death has affected all those Collegians who knew him. From the outset there

\footnotetext{
61 A student's suicide: his letter to the coroner, The Kensington Express, Notting Hill and West London Examiner, 1920-07-23, p. 3. Henning writes that she was English. See C.G. Henning, Fagan, Johannes Jacobus, in C.J. Beyers (Editor-inchief), Dictionary of South African Biography 4, p. 152. Cottrell's suicide by taking "cyanide of potassium", the conclusion was also "Suicide during temporary insanity". See: Suicide in a cave: year-old threat fulfilled, The Kensington Express, Notting Hill and West London Examiner no. 1268 of 17 July 1920, p. 3. Obituary: Johannes J. Fagan, The R.C.M. Magazine 16(3), 1920, p. 29.
} 
was something of a tragic quality about him. In his short life - (he was but 22 when he died) - he had already had to fight a battle extending over several years with serious illhealth. This became so acute that for a time he had to return to his home in South Africa, but with wonderful courage he rallied and returned to work at College once more. He was intensely musical. It was difficult to say whether his abilities lay most strongly in the direction of composition or pianoforte playing. He was eagerly interested in both; he had also for his joy and pain the true artist's discontent with his work. At the time of his death he had just completed a pianoforte trio ${ }^{65}$ and was planning a composition which he thought would be the best thing he had ever done. It is, perhaps, no breach of confidence to tell the world this much of the event which finally undermined his health:In March the singularly charming and beautiful girl to whom he had just become engaged died suddenly within 24 hours from influenza, and carried with her into the beyond his happiest hopes for life. He never rallied from the shock, and though he made great efforts to continue his work his health became steadily worse. Probably few people ever met death more gladly than he. He would have said with R. L. Stevenson:-

This be the verse you grave for me,

"Here he lies where he longed to be;

Home is the sailor, home from the sea,

And the hunter home from the hill."

Fagan's death is not mentioned in Allen's “Director's Terminal Report on Midsummer Term, 1920" which is included in the Minutes of the Executive and Finance Committees of 14 October $1920 .^{66}$

The South African College of Music in Cape Town published an anonymous obituary in the Quarterly Bulletin of the S.A. College of Music. ${ }^{67}$

\section{IN MEMORIAM}

JOHANNES FAGAN, 1898-1920

The death of Johannes Fagan, in London, under the most tragic circumstances has come as a great shock to all who knew him, and has left a blank in the world of South African Music that is not easy to estimate. For there is no manner of question that Fagan was no ordinarily talented student, he was far more than this, he was one who, had he lived, would most certainly have cut a very deep mark in the future history of South

\footnotetext{
65 According to the list of Fagan's works, the last nineteen bars of this composition are missing. G. Fagan, Fagan, Johannes Jacobus, in J.P. Malan (ed), South African Music Encyclopedia 2, p. 51. 
African music, if not in that of the great world of music that knows no national boundaries. Possessed of the real creative fire as he was, with that highly sensitive and impressionable nature that is the possession of none but those marked out as the especially favoured, and gifted ones, he was one not readily understood by those whose course of life runs on more commonplace lines, but to those who, like the present writer, knew his every mood and saw the logical unity of actions, thoughts and impressions that to the casual observer seemed mere idiosyncrasies, he seemed to be destined either for the highest goals that Art affords, or for the bitter tragedy that is the lot of all such natures if placed in an environment antagonistic to their development, or if added to this hypersensitive nature there is some physical weakness that makes its possessor unable to bear the shock of adverse circumstances. To men like Fagan one or the other of these fates is inevitable, a life of serene and respectable mediocrity is not possible to them, it is the price they must pay for the gifts the Gods have showered on them. Had his physical health been equal to his artistic gifts there is no prophesying to what heights those gifts might have carried him, but, alas! now all need for prophecy is gone. The ill-health that for the last four or five years dogged his footsteps, the fatal gift of intense introspection that was to a great extent the result of ill-health, and which covered at times what was, by nature, a remarkable buoyant and joyous soul, with a dark mantle of depression have done their fatal work, and not only his intimate friends and his acquaintances at the College of Music, but South Africa as a whole has every cause to bewail the loss of one of the most gifted boys that this country has ever produced. Personally I, who knew him so well, loved him as the real first-born son of his Alma Mater, and looked upon him as the prospective heir of whatever good the years spent in the service of this country's music might amass, find it impossible to bring myself to write biographical details of the six or seven years of our acquaintance, and can only cry with the old poet: "But the beautiful must perish!" I am sure, however, that the whole College will join with me in rendering our deepest condolences to his parents, and especially to his sisters Hettie and Sophia who were in London with him at the time of his death.

Johannes Fagan was cremated in London and his ashes interred in the family grave in the cemetery of the Dutch Reformed Church in Tulbagh [Figure 5] where he was born. ${ }^{68}$ The grave stone mentions his father (Henry Allan Fagan), his mother (Catherina Susanna Fagan), two brothers who died very young (Laurens J. Fagan at five years and Albertus P. Fagan at four years) and his own name, Johannes J. Fagan. ${ }^{69}$

68 C.G. Henning, Fagan, Johannes Jacobus, in C.J. Beyers (Editor-in-chief), Dictionary of South African Biography 4, p. 152; Personal communication: Mrs Gwen Fagan, wife of Mr Gawie Fagan, Cape Town, 2006-07-30. Gideon Fagan would later, in 1930, compose one of the most touching Afrikaans songs, Klein sonneskyn, on a poem by A.G. Visser. It tells of a mother who has lost her child. See J.P. Malan, Fagan, Gideon, in J.P. Malan (ed), South African Music Encyclopedia 2 (Cape Town, 1982), p. 49. 


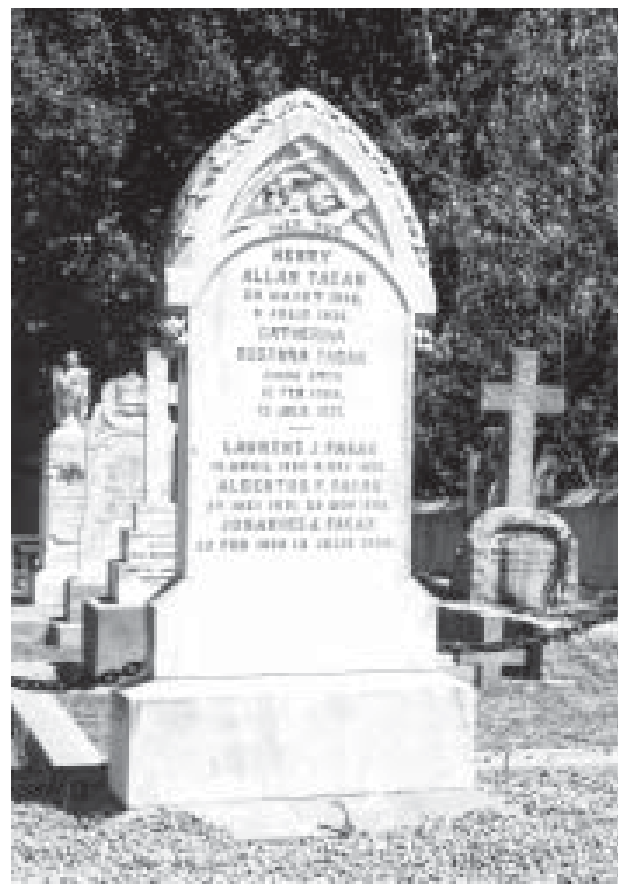

Figure 5: The tombstone in which Johannes Fagan's ashes are interred at the Oude Kerk in Tulbagh (Photograph: Gawie Fagan)

\section{Conclusions}

The death of Johannes Fagan at only 22 years of age in London has not previously been the topic of academic investigation, perhaps because of the sad circumstances of his suicide. The little specific evidence found in London does not suggest that he was officially recognised as a promising composer or pianist. He never performed at any of the RCM's student concerts nor were any of his compositions performed in them.

Parry delivered his last Director's Address to the students of the RCM (possibly read by Johannes Fagan in The R.C.M. Magazine) on 29 April 1918, less than six months before his death at 70. When one considers Johannes Fagan's fate, the following words seem ironic: ${ }^{70}$

But if a man has lived generously and frankly and kindly it helps his old age to be genial and kindly and happy. Even if adverse fates have dealt cruelly with him he has such 
compensations as help him to smile still with the sense that he cannot be defeated-and it does not matter much if the time is short before him, when the good long time behind him is a constant pleasure and content to look back to.

So when you begin to think about it, it will be helpful to remember that youth must soon be gone, and to try to provide for the possibility of old age, however keen and eager you may be. And that it will be most worth getting to if your memories are plentifully worth cherishing; and never bring you anything but a quiet sense of contentment in having done your best to live a life that was worth recalling - that the fight has been won by the better self against the worser self-and that you have contrived to help the world to be a better place to live in before it is time to take leave of it.

It is a sad fact that, apart from his enrolment form, the fine obituary in The R.C.M. Magazine to the memory of Johannes Fagan is the only place where his name can be found in the documents and publications of the Royal College of Music in London.

One has to deduce that in spite of his apparent talent, Johannes Fagan did not have enough time in his short life to establish himself as one of South Africa's great or greatest composers. He only left a small number of works, some unfinished, and very few published. One wonders whether his name as a composer is due to the connection with the success of his brother Gideon. In Bouws's book Suid-Afrikaanse komponiste van vandag en gister (South African composers of today and yesterday) Bouws discusses the brothers Fagan in a chapter called "Johannes en Gideon Fagan", indicating that the two brothers were regarded as a package. ${ }^{71}$ It could therefore be that Johannes Fagan received undue recognition because of this connection. This article has established that, in addition to the fact that Johannes Fagan did not leave many compositions, he was not very successful at the RCM where he was surrounded by other very accomplished South African students. His lack of success was most probably due to his bad health and the death of his English fiancée.

About two years after Johannes Fagan's death, the 17-year-old Gideon Fagan (19041980), whose musical development had been nurtured by his elder brother Johannes, enrolled on 30 September 1922 at the Royal College of Music, in this way fulfilling Johannes's dreams. Like Johannes, he studied with Vaughan Williams. ${ }^{72}$ Gideon Fagan became one of South Africa's most successful composers and conductors.

J. Bouws, Suid-Afrikaanse komponiste van vandag en gister (Kaapstad, 1957), pp. 49-51.

G.F. Stegmann and J. May, Fagan, Gideon, in S. Sadie (ed), The New Grove Dictionary of Music and Musicians 8 (2nd ed), (London, 2001), p. 513. 